\title{
INTERAKSI ANTARA MUSLIM DENGAN NON MUSLIM DALAM PERSPEKTIF ISLAM
}

\author{
Oleh : \\ Akhmad Zaeni \\ IAI Al - Falah As - sunniyyah Kencong \\ akhmadzaeni535@gmail.com
}

\begin{abstract}
The relationship between muslims and non-muslims history of the relationship of theProphet Muhammad and the Muslims with the Christians and Jews is real. Islam recognizes the plurality of the religion and does not coerce others in doing the dakwah. Islam does not come to kill and destroy other religions, but to make mutual relationship and live peacefully and cooperatively side by side. Especially in term of social interaction (mu'amalah) and daily interaction with the non-Muslims. Islam teaches flexibility and mutual respect.
\end{abstract}

Keywords: Tolerance, Religion, Islam

ABSTRAK

Interaksi antara muslim dengan non muslim tercantum dalam sejarah tentang hubungan Nabi Muhammad dan umat Islam dengan kaum Nashrani dan Yahudi.nyata bahwa Islam mengakui pluralitas agama dan tidak melakukan pemaksaan dalam berdakwah. Islam tidak datang untuk menghabisi dan memusnahkan agama lain, melainkan agar para pemeluk agama saling hidup damai berdampingan dan bekerja sama. Terlebih dalam masalah interaksi sosial (mu'amalab) dan pergaulan sehari-hari dengan orang kafir, Islam mengajarkan keluwesan dan sikap saling menghargai

Kata kunci: toleransi, agama, Islam

\section{Pendahuluan}

Manusia adalah makhluk individu sekaligus makhluk sosial, yang selama hidupnya akan selalu membutuhkan orang lain dan saling bergantungan. Ketika individu hidup dengan individu lain, akan terjadi hubungan timbal balik atau yang disebut dengan interaksi sosial. Interaksi sosial terjadi apabila satu individu melakukan tindakan

sehingga menimbulkan reaksi dari individu lain.

Jurnal Auladuna | 18

Vol.DI. №.02. April 2019 
Interaksi sosial sangat penting bagi kehidupan sosial. Hal ini merupakan proses kehidupan sosial dalam kehidupan sehari-hari, seorang individu pasti mengadakan hubungan atau interaksi dengan individu yang lain. Gillin dan Gillin (dalam Soekanto, 2009:55), "Interaksi sosial merupakan hubungan sosial yang dinamis, yang menyangkut hubungan orang perorang antar kelompok dengan kelompok manusia maupun antar orang perseorangan dengan kelompok

manusiaa yang berbeda latar belakang dan agama. ${ }^{1}$

Belakangan ini banyak kesenjangan sosial di dalam masyarakat yang mengatasnamakan agama. Seperti banyak kasus bom yang mengatas namakan agama bom yang terdapat di salah satu gereja di surabaya.

Semua agama tidak membenarkan hal tersebut salah satunya agama islam dalam Surat al-Anbiya ayat 107 dinyatakan, "Dan tiadalah Kami mengutus kamu, melainkan untuk (menjadi) rahmat bagi semesta alam". Dengan lugas dinyatakan bahwa Islam merupakan agama yang membawa rahmat dan kesejahteraan bagi semua seluruh alam semesta, ter- masuk hewan, tumbuhan dan jin. Kezaliman terhadap binatang, akan dipertanggungjawabkan di Akhirat. Dalam sebuah hadis dinyatakan, Siapa yang membunuh burung kecil, tanpa alasan yang dibenarkan (abast), maka burung itu akan melayangkan 'somasi' di badapan Allah berupa tuntutan: Ya Tubanku, orang itu telah membunubku tanpa alasan, ia membunubku tanpa kemanfaatan. ${ }^{2}$

Senada dengan Hadis di atas, Shahabat Abdullah bin 'Amr berkata bahwasanya Rasulullah pernah bersabda, "Siapa yang membunub burung, atau hewan lain yang lebih kecil darinya tanpa hak, maka Allah akan meminta pertanggungjawaban kepadanya.'Rasulullah saat ditanya tentang hak burung tersebut, beliau bersabda, "Burung tersebut memiliki bak untuk disembelih untuk kemudian dimakan, bukan dipotong lehernya untuk kemudian dilempar (tersia-sia)."’3

Sungguh, hak hewan dihormati oleh Islam. Apapun bentuk ke- sewenang-wenangan dan kezaliman terhadap hewan, akan mendapat kecaman dari Agama. Dalam sebuah hadis diriwayatkan, "Sesunggubnya Rasulullah bersabda: Seorang wanita disiksa sebab seekor kucing yang dikurungnya. Ia tidak memberinya makan, hingga akhirnya kucing itu mati

\footnotetext{
${ }^{1}$ Soekanto, Soerjono. 2009. Sosiologi: Suatu Pengantar. Jakarta; PT. Grafindo Persada

2 Al-Bantani (Muhammad bin Umar), Tausyikh 'ala Ibn Qasim, (Surabaya: TB. Al-Hidayah, tt), hal. 21

${ }^{3}$ Al-Imam Ibn Hibban, Shahih Ibn Hibban (Beirut: Muassasah al-Risalah, 1993), cet. III, jilid XIII, hal. 214, dan al-Imam al-Thabrani, al-Mu'jam al-Kabir (Musol: Maktab ah al-'Ulum wa al-Hikam, 1983), cet. II, jilid VII hal. 317

Vol.DI. No.I2. April 2019 
karena kelaparan. Ia juga tidak melepaskannya, bingga kucing tadi bisa mencari makan dengan sendirinya". Rasulullah menambahkan, "Wanita tadi dibukum masuk Neraka". ${ }^{4}$

Demikian sebagian penghormatan yang diberikan Islam terhadap hewan. Dibandingkan dengan hewan dan tumbuhan, manusia adalah makhluk yang sempurna dalam Islam. Berdasarkan ajaran Islam, Islam mengajarkan untuk mendorong para pengikutnya agar bersikap toleransi kepada penganut agama dan keyakinan lain serta bersikap positif terhadap keberagaman, karena Allah menjadikan manusia sebagai khalifah yang mempunyai tanggung jawab untuk membangun dan memakmurkan bumi, baik secara material maupun spiritual.

\section{Interaksi Sosial}

Dalam kehidupan masyarakat, interaksi sosial merupakan realitas yang nyata, hal ini tidak terlepas dari hakikat manusia sebagai makhluk sosial, yang harus saling berhubungan antara individu satu dengan individu yang lain, atau kelompok satu dengan kelompok yang lain. Interaksi juga menunjukkan kepada perubahan yang dinamis yang menyebabkan suatu individu atau kelompok mengalami perubahan. Menurut Soerjono Soekanto, interaksi sosial adalah proses dimana orang-orang berkomunikasi saling mempengaruhi dalam pikiran dan tindakan. Interaksi sosial terjadi dalam masyarakat memiliki berbagai baik bentuk asosiatif atau bentuk disosiatif. $^{5}$

Maryati dan Suryawati membagi interaksi sosial menjadi tiga macam, yaitu interaksi antara individu dan individu, interaksi antara individu dan kelompok, dan interaksi antara kelompok dan kelompok (Maryati dan Suryati, 2003). ${ }^{6}$

Pada dasarnya, interaksi sosial merupakan bentuk hubungan sosial yang luas, karena interaksi sosial tidak hanya dapat diamati melalui perkataan atau secara verbal saja, melainkan melalui gerak tubuh atau secara non verbal interaksi sosial pula dapat berlangsung. Akan tetapi, interaksi sosial tidak dapat sedemikian rupa terlaksana tanpa adanya pemicu terjadinya interaksi sosial.

Kelangsungan interaksi sosial merupakan hal yang kompleks walaupun pada dasarnya interaksi sosial adalah sesuatu yang sederhana karena terjadi melalui hal-hal yang terkadang

\footnotetext{
${ }^{4}$ Al-Imam al-Hakim,al-Mustadrak 'Ala al-Shahihain (Beirut: Dar al-Kutub al-'Ilmiyah, 1990), cet. I, jilid IV, hal.261; AlImam al-Baihaqi,al-Sunan al-Kubra, (Mekkah al-Mukarramah, Maktabah Dar al-Baz, 1994), jilid IX, hal. 86; Al-Imam al-Darimi,Sunan al-Darimy, (Beirut: Dar al-Kitab al- 'Araby, 1407 H), I jilid II, hal. 115

${ }^{5}$ Soekanto, Soerjono. (2010). Sosiologi Suatu Pengantar. Jakarta: Raja Grafindo

Persada

${ }^{6}$ Maryati dan Suryati. 2003. Jurnal SDM. Http://jurnal-sdm.blogspot.com/2009/05/interaksi-sosial-definisibentuk-ciri.html. Diakses pada tanggal 25 Maret 2010

لurnal Auladuna | 20

Vol.DI. No.I2. April 2019
} 
jarang disadari bahwa yang dilakukan itu sebagai proses interaksi sosial. Ada beberapa faktor yang turut mempengaruhi keefektifan interaksi sosial individu.

Agama Islam adalah agama rahmat untuk mewujudkan cita-cita besar sebagai agama rabmatan lil'alamin diperlukan kerjasama antar umat manusia, baik intern umat Islam maupun secara ektern dengan umat nonmuslim.

Prinsip-prinsip interaksi sosial dengan nonmuslim adalah:

\section{Saling Mengenal (memahami)}

Prinsip ini disebutkan dalam alquran surah al-Hujurat ayat 13 :

"Hai manusia, sesungguhnya Kami menciptakan kamu dari seorang laki-laki dan seorang perempuan dan menjadikan kamu berbangsa - bangsa dan bersuku-suku supaya kamu saling kenal mengenal. Sesungguhnya orang yang paling mulia di antara kamu di sisi Allah ialah orang yang paling bertakwa di antara kamu.Sesungguhnya Allah Maha Mengetahui lagi Maha Mengenal (TQS. al-Hujurat: 13).

Ayat di atas adalah dasar interaksi sosial antar sesama manusia. Interaksi sosial yang dimaksud adalah aksi hubungan yang bersifat timbal balik , pentingnya untuk saling mengenal dan saling berinteraksi antar satu sama lain, tapi pada aspek-aspek hubungan yang bersifat umum tidak dalam hal yang bersifat ritual keagamaan, melainkan saling menghargai dan menghormati dalam dimensi sosial kemasyarakatan. Jika relasi interaksi sosial berkenaan dengan aspek keagamaan maka acuannya adalah al-Qur'an surah al -Kafirun ayat 6:

\section{"Untukemu agamamu dan untukekulah agamaku (TQS. al-Kafirun: 6)".}

\section{Kompromi}

Alquran menganjurkan untuk mencari titik temu atau kompromi antar pemeluk agama, menekankan dalam interaksi sosial jika tidak menemukan persamaan, maka hendaknya masing-masing pihak menghargai dan mengakui eksistensi pihak lain dan tidak salig menyalahkan seperti disebutkan dalam Al - Quran surah Ali Imran ayat 64 
Katakanlah: "Hai Ahlul Kitab, marilah (berpegang) kepada suatu kalimat (ketetapan) yang tidak ada perselisihan antara kami dan kamu, bahwa tidak kita sembah kecuali Allah dan tidak kita persekutukan Dia dengan sesuatu pun dan tidak (pula) sebagiankita menjadikan sebagian yang lain sebagai Rabb-Rabb selain Allah". Jika mereka berpaling maka katakanlah kepada mereka: "Saksikanlah, bahwa kami adalah orang-orang yang berserah diri kepada Allah (TQS. Ali Imran: 64).

\section{Regulasi Tertulis}

Dalam lingkup yang lebih luas dan kompleks yang mengatur hubungan umat Islam dan nonmuslim Rasulullah SAW mendokumentasikannya, tujuannya adalah untuk menjelaskan komitmen masing-masing pihak dan menegaskan batasan hak dan kewajiban serta sanksi.

Dalam kitab Majmu'atul watsaiqis Siyasah, menyebutkan bahwa dokumentasi yang dibuat antara muslim dan nonmuslim memuat 47 klausal. Klausal 24 sampai 57 memuat perjanjian damai dengan yahudi.Klausal 25-35 membicarakan hubungan dengan orang-orang yahudi dari Aus dan Khazraj.

Klausal 45 memuat perjanjian yang lebih meluas kepada sekutu-sekutu muslim dan yahudi yang lain. Bila dicermati dokumen ini dibangun atas kerjasama untuk menegakkan keadilan, kesalahan, perdamaian, dan pertahanan keamanan.

Dalam konteks ke Indonesiaan, keragaman budaya adalah realitas sosial yang niscaya, namun dalam prakteknya tidak selalu dibarengi dengan penerimaan positif dikalangan umat beragama. Justru tidak sedikit fakta yang menunjukkan fenomena sebaliknya. Keberagaman telah memberi andil munculnya ketegangan dan konflik. Masih segar dalam ingatan kasus pembakaran masjid di Papua dan yang paling baru adalah pembakaran gereja di Aceh Sigkil, 
Provinsi Nangroe Aceh Darussalam.Keberagaman yang mestinya menjadi Social Capital justru kontra produktif dengan penciptaan tatanan kehidupan berbangsa yang damai, harmonis dan toleran.

Kerahmatan Islam mestinya tidak hanya monopoli bagi umat Islam tapi juga dapat terasa kepada umat nonmuslim, oleh kaena itu perlu objektivikasi nilai Islam. Menurut Nurcholish Madjid (Nurcholish, 1995: 270), yang dimaksud objektivikasi nilai islam adalah elaborasi nilai-nilai internal islam ke dalam kategori objektif. ${ }^{7}$ Objektivikasi sepadan dengan ekternalisasi yaitu kegiatan konkritisasi nilai-nilai yang diyakini dan dihayati oleh setiap pribadi muslim.

\section{Persamaan}

Prinsip persamaan mutlak dalam Islam untuk membina hubungan sesama manusia, tidak boleh ada diskriminasi. Sebagaimana dijelaskan Rasulullah SAW dalam hadits yang diriwayatkan oleh Anas bin Malik sebagai berikut:

(Asal usul) Manusia adalah sama, tidak ubahnya seperti gigi. Kelebihan seseorang hanya terletak pada ketaqwaannya kepada Allah SW'T. Dalam lafaz yang lain diriwayatkan oleh al-Hasan :

"Kelebihan hanya terdapat dalam kebaikan. Seseorang merasa lebih dengan keberadaan saudaranya. Kebaikan seseorang terlihat bila yang dianggap benar itu sama dengan kebenaran yang dianggapnya sendiri”

Dinyatakan dengan tegas bahwa di depan kebenaran dan hukum, semua harus dianggap sama dan terjamin kehormatan, harga diri dan kebebasannya. Kelebihan seseorang hanya dilihat dari sejauh mana konsistennya terhadap kebenaran dan undang serta sebesar apa antusiasnya untuk berbuat kebajikan dan menjauhi diri dari tindakan melanggar hukum, kejahatan dan kezaliman.

Biografi Nabi Muhammad Saw. mencatat implementasi prinsip persamaan di atas seperti terlihat dari kasus Usamah bin Yazid.

\footnotetext{
${ }^{7}$ Nurcholish Madjid, Pintu-Pintu Menuju Tuhan, diterbitkan oleh Paramadina, 1995, hal. 270.
} 
Usama yang dikenal sebagai sahabat terdekat Rasulullah itu, mencoba memberikan dispensasi hukuman bagi Fatimah binti alAswad al-Makhzumiyah yang tertangkap basah melakukan tindakan kriminal mencuri. Rasulullah tersinggung dan marah, lalu berkata kepada Usamah:

"Umat terdahulu binasa lantaran bila kaum elit mereka mencuri, dibebaskan, tetapi bila kaum lemah yang mencuri, langsung diadili dan dijatuhi sanksi. Demi Allah, kalau Fatimah putri Muhammad yang mencuri, pasti saya potong tangannya (sebagai sanksi tindakan kriminalnya). (Abdul 'Azhim bin Abdul Qawi Abu Muhammad al-Munziri, wafat 656 H, hal. 3/273)."8

Dari sini, jelas bahwa pada Zaman Rasulullahh SAW persamaan adalah pilar utama keadilan sosial.

Persamaan dan keadilan ibarat dua sisi logam yang bila salah satu sisinya hilang, sisi yang lain tidak ada artinya. Stabilitas sosial dan masyarakat tidak akan tercapai, bila keduanya menjadi sirna. Untuk itu, merupakan suatu keharusan memberlakukan keadilan kepada semua pihak tanpa melihat perbedaan status sosial.

Menurut ajaran Islam, siapa saja harus memperoleh keadilan, baik raja maupun rakyat jelata, atasan atau bawahan, dan muslim atau nonmuslim, karena manusia adalah sama.

Persamaan dan keadilan yang diajarkan Islam tersebut selain melindungi hak setiap orang di depan siapapun, juga menolak sikap deskriminatif. Dengan menghormati prinsip yang mulia ini, diyakini bahwa perbedaan ras, suku dan agama atau kemajemukan tidak menjadi penyebab atau alasan terjadinya konflik dan tindakan

\footnotetext{
${ }^{8}$ Hadis Riwayat Bukhari, Muslim, Abu Daud, at-Tarmizi, an-Nasa'I dan Ibnu Majah. Lihat lebih lanjut buku "al-Targhib wa al-Tarhib min al-Hadist al-Syarif' (Himbauan dan Peringatan dari Hadis yang mulia) karangan al-Munziri (Abdul 'Azhim bin Abdul Qawi Abu Muhammad, wafat 656 H), hal. 3/173, Tahqiq Ibrahim Syamsuddin, Dar al-Kutub al-Ilmiyah, Beirut, tahun $1417 \mathrm{H}$ 
kekerasan, tetapi seharusnya menjadi motif ta'aruf atau saling mengenal.

3. Berbuat Baik

Dalam Arti Surat Al - Mumtahanah ayat 8 adalah " Allah tidak melarang kamu untuk berbuat baik dan berlaku adil terhadap orang-orang yang tiada memerangimu karena agama dan tidak (pula) mengusir kamu dari negerimu”. Sesungguhnya Allah menyukai orang-orang yang berlaku adil. TAFSIR AYAT 8.

"Allah tidak akan melarang kalian untuk berbuat baik kepada orang-orang yang tidak memerangi agama kalian dan tidak mengusir kalian dari kampong halaman kalian. Kalian diperbolehkan bersilaturrahim dengan mereka atau saling mengasihi sesama tetangga. Allah juga tidak melarang kalian memperlakukan mereka dengan adil. Allah mencintai orang-orang yang berlaku adil dan membersihkan jiwa mereka"9

Maksudnya adalah Allah tidak melarang untuk mencintai mereka dan memperlakukan mereka dengan adil. Tafsir Al-Wajiz / Prof. Dr. Wahbah az-Zuhaili Ketika ayat-ayat yang mulia ini turun, dimana ayat-ayat tersebut mendorong untuk memusihi orang-orang kafir, maka kaum mumin mendapat pengaruh besar sekali sehingga mereka mau melaksanakannya dengan sebenar-benarnya dan mereka merasa berdosa ketika menyambung tali silaturrahim kepada kerabat mereka yang masih musyrik dan mereka mengira bahwa yang demikian termasuk ke dalam hal yang dilarang Allah, maka Allah Subhaanahu wa Ta'aala memberitahukan bahwa hal itu (berbuat baik dan bersikap adil terhadap orang-orang kafir yang tidak memerangi) tidak termasuk ke dalam hal yang dilarang Allah Subhaanahu wa Ta'aala, Dia berfirman, "Allah tidak melarang kamu berbuat baik dan berlaku adil terhadap orang-orang yang tidak memerangimu dalam urusan agama dan tidak mengusir."

\footnotetext{
${ }^{9}$ al-Majilis al-'A'la li al-Syuun al-Islamiyah, Alih bahasa semua ayat Al-Quran dalam makalah ke bahasa Indonesia memakai buku 'al-Muntakhab fir Tafsir al-Quran al-Karim', diterbitkan oleh yang berada di Kementerian Wakaf Republik Arab Mesir dalam rangka memperingati Hut 1000 tahun Al-Azhar Al-Syarif, cetakan ke tujuh tahun $1983 \mathrm{M} / 1402 \mathrm{H}$ Vol.DI. No.QZ2. April 2019 
Maksudnya, Allah Subhaanahu wa Ta'aala tidak melarang kamu berbuat baik, bersilaturrahim, membalas kebaikan dan berbuat adil kepada kaum musyrikin baik kerabatmu maupun selain mereka yang tidak memerangi kamu dalam urusan agama dan tidak mengusir kamu dari kampung halamanmu, maka tidak mengapa bagimu menyambung tali silaturrahim dengan mereka, karena menyambung tali silaturrahim dalam keadaan ini tidak ada mafsadatnya sebagaimana firman Allah Ta'ala tentang kedua orang tua yang masih musyrik, "Dan jika keduanya memaksamu untuk mempersekutukan dengan Aku sesuatu yang tidak ada pengetahuanmu tentang itu, maka janganlah kamu mengikuti keduanya, dan pergaulilah keduanya di dunia dengan baik, dan ikutilah jalan orang yang kembali kepada-Ku, kemudian hanya kepada-Kulah kembalimu, maka Kuberitakan kepadamu apa yang telah kamu kerjakan.

\section{Non Muslim}

Non muslim adalah orang yang tidak menganut agama Islam. Tentu saja maksudnya tidak mengarah pada suatu kelompok agama saja, tetapi akan mencakup sejumlah agama dalam segala bentuk kepercayaan dan berbagai ritualnya.

Al-Quran menyebutkan kelompok nonmuslim secara umum seperti tercantum dalam al-Quran surah al-Hajj ayat 17:

"Sesungguhnya orang-orang yang beriman, orang-orang Yahudi, orangorang Shaabi-iin orang-orang Nasrani, orang-orang Majusi dan orang-orang musyrik, Allah akan memberi keputusan di antara mereka pada hari kiamat. Sesungguhnya Allah menyaksikan segala sesuatu (TQS. al-Hajj: 17).,"10

Demikian juga pada al-Quran surah al-Jasiyah ayat 24:

"Dan mereka berkata: "Kehidupan ini tidak lain hanyalah kehidupan di dunia saja, kita mati dan kita hidup dan tidak ada yang akan membinasakan kita selain masa", dan mereka sekali-kali tidak

mempunyai pengetahuan tentang itu, mereka tidak lain hanyalah menduga-duga saja (TQS. al-Jasiyah: 24).”

\footnotetext{
${ }^{10}$ Software Al-Quran Terjemah Bahasa Indonesia Jurnal Auladuna | 26
} 
Berdasarkan penjelasan alquran terdapat lima kelompok yang dikategorikan sebagai nonmuslim, yaitu:

Ash-Shabi'ah, yaitu kelompok yang mempercayai prngaruh planet terhadap alam semesta. ${ }^{11}$

1. Al-Majus, adalah para penyembah api yang mempercayai bahwa jagat raya dikontrol oleh dua sosok Tuhan, yaitu Tuhan Cahaya dan Tuhan Gelap yang masing-masing bergerak kepada yang baik dan yang jahat, yang bahagia dan yang celaka dan seterusnya.

2. Al-Musyrikun, kelompok yang mengakui bahwa ketuhanan Allah SWT, tapi dalam ritual mempersekutukannya dengan yang lain seperti menyembah berhala, matahari dan malaikat.

3. Al-Dahriyah, kelompok ini selain tidak mengakui bahwa dalam alam semesta ini ada yang mengaturnya, juga menolak adanya Tuhan pencipta. Menurut mereka alam ini eksis dengan sendirinya. Kelompok ini agaknya identik dengan kaum atheis masa kini.

4. Ahli Kitab. Dalam hal ini terdapat dua pendapat ulama. Pertama, Mazhabi Hanafi berpendapat bahwa yang termasuk Ahli Kitab adalah orang yang menganut salah satu agama Samawi yang mempunyai kitab suci seperti Taurat, Injil, Suhuf, Zabur, dan lainnya. Tapi menurut Imam Syafii dan Hanbali, pengertian Ahli Kitab terbatas pada kaum Yahudi dan Nasrani. Kelompok nonmuslim ini disebut juga dengan Ahli Zimmah yaitu komunitas Yahudi atau Nasrani yang berdomisili di wilayah umat Islam dan mendapat perlindungan pemerintah muslim (Dapat dirujuk kembali dalam Al-Qurtubi, al-Tabari, Ibnu Katsir yang menjelaskan lebih luas tentang pengertian kelompok nonmuslim yang disebut dalam ayat tersebut. Selain itu, 'al-Mausu'ah al- Muyassarah fi aladyan wa al-mazahib al-mu'ashirah' dan 'huriyah al-mu'taqad al-diiny li ghair almuslimin fi zhilal samahat al-Islam’ oleh Ali Abdul ‘al al-Syinawi).

\section{Penutup}

${ }^{11}$ Ali Abdul al-Syinawi 'huriyah al-mu'taqad al-diiny li ghair al-muslimin fi zhilal samaahat al Islam oleh Ali Abdul 'al al-Syinawi, hal. 170, yang merujuk 'kitab Isytirakiyah al-Islam' oleh Mustafa al-Siba'I dan buku 'Al-Amwal' oleh al-Hafiz bin Salam dan 'Abqariyah Umar' oleh Abbas Mahmud al-'Akad. Vol.DI. No.QZ2. April 2019

Jurnal Aulduna | 27 
Interaksi sosial muslim dengan non muslim adalah sikap saling menghargai dan menghormati di sosial masyarakatan di kehidupan sehari hari. Interaksi sosial di dalam agama islam juga didasarkan kepada ajaran al-Quran dan al-hadits (agama Islam). Di dalamnya berisi tentang saling mengenal (memahami), membangun budaya kompromi, berbuat baik, berperilaku adil dan saling membantu, regulasi tertulis (dokumen) yang menunjukkan komitmen dan konsisten serta persamaan dalam arti yang seadil-adilnya. Dalam isi nilai tersebut direkomendasikan untuk menjadi landasan dalam menangani masalah multikultur, multiagama, multibahasa, multibangsa atau kehidupan yang plural secara umum.

\section{Pustaka Acuan}

Al-Bantani (Muhammad bin Umar), Tausyikh 'ala Ibn Qasim, (Surabaya: TB. Al-Hidayah, tt), hal. 21.

Ali Abdul al-Syinawi 'buriyah al-mu'taqad al-diiny li ghair al-muslimin fi zhilal samaahat al Islam oleh Ali Abdul 'al al-Syinawi, hal. 170, yang merujuk 'kitab Isytirakiyah al-Islam' oleh Mustafa al-Siba'I dan buku 'Al-Amwal' oleh al-Hafiz bin Salam dan 'Abqariyah Umar' oleh Abbas Mahmud al-'Akad.

Al-Imam al-Hakim,al-Mustadrak' 'Ala al-Shahihain (Beirut: Dar al-Kutub al-'Ilmiyah, 1990), cet. I, jilid IV, hal.261; Al-Imam al-Baihaqi,al-Sunan al-Kubra, (Mekkah al-Mukarramah, Maktabah Dar al-Baz, 1994), jilid IX, hal. 86; Al-Imam al-Darimi,Sunan al-Darimy, (Beirut: Dar al-Kitab al- 'Araby, 1407 H), I jilid II, hal. 115.

al-Majilis al-'A'la li al-Syuun al-Islamiyah, Alih bahasa semua ayat Al-Quran dalam makalah ke bahasa Indonesia memakai buku 'al-Muntakhab fir Tafsir al-Quran al-Karim', diterbitkan oleh yang berada di Kementerian Wakaf Republik Arab Mesir dalam rangka memperingati Hut 1000 tahun Al-Azhar Al-Syarif, cetakan ke tujuh tahun $1983 \mathrm{M} / 1402 \mathrm{H}$.

Andi Rahman.2015. Jurnal Al-Munzir. http:// http://ejournal.iainkendari.ac.id/al-munzir Diakses Pada 20 Februari 2019

http://ejournal.iainkendari.ac.id/al-munzir/article/download/758/692

Maryati dan Suryati. 2003. Jurnal SDM. Http://jurnal-sdm.blogspot.com/2009/05/interaksisosial-definisi-bentuk-ciri.html. Diakses pada tanggal 25 Maret 2010 Mushaf al-Quran al-Karim

Nurcholish Madjid, Pintu-Pintu Menuju Tuhan, diterbitkan oleh Paramadina, 1995, hal. 27 
Soekanto, Soerjono. (2010). Sosiologi Suatu Pengantar. Jakarta: Raja Grafindo Persada

Soekanto, Soerjono. 2009. Sosiologi: Suatu Pengantar. Jakarta; PT. Grafindo Persada. 